\title{
Impact of Flooding on Quality of Life in Shariatpur of Bangladesh: A Cross-Sectional Study
}

\section{Md Abeed Hasan ${ }^{1}$, Bikash Chandra Das ${ }^{1}$, Eshita Farha Tonni ${ }^{1}$ and Golam Mohammad ${ }^{2 *}$}

${ }^{1}$ Faculty of Public Health, North South University, Bangladesh

${ }^{2}$ Associate Professor, Department of Pharmacy, Gono Bishwabidyalaya, Bangladesh

*Corresponding Author: Golam Mohammad, Associate Professor, Department of Pharmacy, Gono Bishwabidyalaya, Bangladesh.
Received: September 20, 2021

Published: December 08, 2021

(C) All rights are reserved by Md Abeed

Hasan., et al.

\begin{abstract}
Background: In Bangladesh, water-induced disasters, including floods, account for over $30 \%$ of the overall loss of life due to natural disasters. On the one hand, short-range geographical heterogeneity, young and complex geology, and uneven temporal distribution of rainfall contribute significantly to the incidence of such hazards caused by water, vulnerability to such hazards and weaknesses of people primarily due to poverty, and lack of well-preparedness explain the escalating loss of lives and property. It can create significant social and welfare problems that can last for years, not only because of the floods (the primary stressor), but also because of the persistent secondary stressors that individuals face as they try to rebuild their lives, properties, and relationships. Floods are known to have an influence on the quality of life of those impacted, who are mostly from underdeveloped nations with limited ability to cope with the catastrophe.

Methods: This cross-sectional analytical study performed in September 2020, one month after the tragedy in the Shariatpur district. In the months of September to November 2020, 384 persons were polled in those Upazillas following flood disasters. The association between flooding and quality of life is investigated in this study.

Results: The average score for quality of life after being harmed by the flood was $26.26 \pm 5.15$. Adults in a flooded area of Shariatpur, Bangladesh, participated in this large-scale cross-sectional study to examine Quality of Life (QoL) and its connection with sociodemographic and clinical factors. In comparison to another study, where Quality of Life was assessed as outstanding 110-89, good 88-67, fair 45-66, and poor 45 on the WHOQOL-BREF scale, the mean quality of life score was $26.26 \pm 5.15$, suggesting a poor quality of life. Conclusion: Emergency preparedness programs must incorporate the psychological effects of flooding to improve quality of life, especially in poor countries with limited resources and infrastructure, such as Bangladesh. The study's purpose is to assess the situation, assess the quality of life and flood-related effects in Bangladesh's flood-affected region, and examine the key factors of floodrelated occurrences. Many people living in flood-affected areas have shown that early action is necessary to improve their quality of life. Flood mitigation should comprise a multi-sartorial approach due to the different underlying causes of people's vulnerability. The outcomes of this study will help policymakers improve early intervention and have major public health implications for healthrelated quality of life.
\end{abstract}

Keywords: Quality of Life; WHOQOL-BREF; Flood

\section{Abbreviations}

AWD: Acute Watery Diarrhoea; HR QoL: HR Quality of Life; MH: Mental Health; PPL: People; PTSD: Post-Traumatic Stress Disorder; QoL: Quality of Life; WHOQOL: World Health Organization Quality of Life

\section{Introduction}

Floods occur regularly in many parts of the country, and they are a part of people's lives for years, with differing magnitudes and rates to which ppl have evolved. In many parts of the world, these floods are usually anticipated and accepted, because they have both 
water and livelihoods while enriching the land. A flood is a water overflow that engulfs soil, close to the bottom townships, or an unusual condition triggered by a tide stream. An accumulation of water from bodies of water can cause flooding, such as a waterway or lake, or as a result of an aggregation of water on soaked arrive in an ethereal flood, or as a result of large natural water basins [4]. The planet is undergoing major climate change that is contributing to a rise in natural disasters. The flood is a devastating tragedy that affects the lives of people. Almost every year it got dilapidated by natural disasters, which no surprise has become an acquaintance to its people [10]. Shariatpur, Bangladesh has seen the worst rainfall in the past year in the Monsoon. It is predicted that flooding and landslides in Shariatpur between July 2020 and August 2020 will have a long-term effect on the social, economic and health sectors.

Floods have important effects on the quality of life linked to health. Living minimally even got interrupted and financial burden therefore turned its way onto psychological disruption [10]. In the context of the recent floods in Shariatpur, screening for psychological issues is important. It started abrogating the least possible ways to earn and the condition got worse to imagine. The quality of life was being hampered under immense financial crisis and food insecurity, which led people to become mentally and psychologically disquiet. The recent flood played a role of a strong catalyst, which provoked the condition to the next level of people's mental breakdown. The tragedy affects individuals in numerous ways, and as a product of alterations in everyday routine and the lack of life roles, many people develop posttraumatic stress disorder (PTSD) [21]. As the water of the Padma and Meghna River flowed $40 \mathrm{~cm}$ above the danger level and an estimated 75,000 people were affected, 2190 families were evacuated this year due to severe flooding [33]. This study was therefore carried out to evaluate the QoL of people who resided in flood-affected areas in Shariatpur.

At the end of the study, we came to stand on a narrow observation that led us to evaluate health status and QoL among adults in the Shariatpur district of Bangladesh. This cross-sectional analysis included 384 participants. Our analysis does not consider the demographic and socio-economic profile of participants that may affect the outcome. This study is about to bring a light, offering a way to see things that are not easily and widely demonstrated, that, how a disease or a natural disaster could be enough to squander lives of people in a developing country and ending up picturing the ruthless reality induced by the flood.
Few research are available on the quality of life of people living in areas vulnerable to natural hazards in less developed/developing nations. This research aims to evaluate the effects of floods that are susceptible to natural disasters in Shariatpur. In see of quickly expanding worldwide portability, the field of medical sciences has become a significant one. The calculation of a population's health status is not only limited to conventional dismalness and death statistics, but this is also related to the evaluation of life's quality as well. life's quality is an integral concept that encompasses fundamental elements like physical well-being, psychology, social ties, economics, personal beliefs, and environmental relationships. "Quality of Life (QoL)" alludes to the patient's sense of wellbeing across a broad spectrum of physiological, emotional, and social work. The proposed study would help to define the quality of life correlated with health in Bangladesh〉s Shariatpur district.

\section{Materials and Methods}

Study design

This cross-sectional analytical study performed in September 2020, one month after the tragedy in the Shariatpur district. Subjects in the study population were randomly selected across 8 Upazila in the Shariatpur district of Bangladesh and the results are assessed by comparing outcomes.

\section{Target population and sample population}

The study population was 20 years or above age group people consisting of both male and female in Shariatpur district who experienced the flood disaster in 2020 and the representative sample population fulfilled the inclusion criteria of the study.

\section{Study site and area}

The research was carried out in Shariatpur's 8 Upazilas (Damudya, Shariatpur Sadar, Zanjira, Naria, Gosairhat, Bhedarganj and Shakhipur). The study area was next to the Padma and Meghna river, which is close to the bottom, heavily vulnerable to flooding area. The majority of the targeted localities are found along the Padma River, which runs through the Shariatpur district. This area's total population is 1,155,824 (Population Census, 2011). Riverine floods have been experienced almost every year by people in this region. On average, the respondents found the flood duration was 50-60 days. 


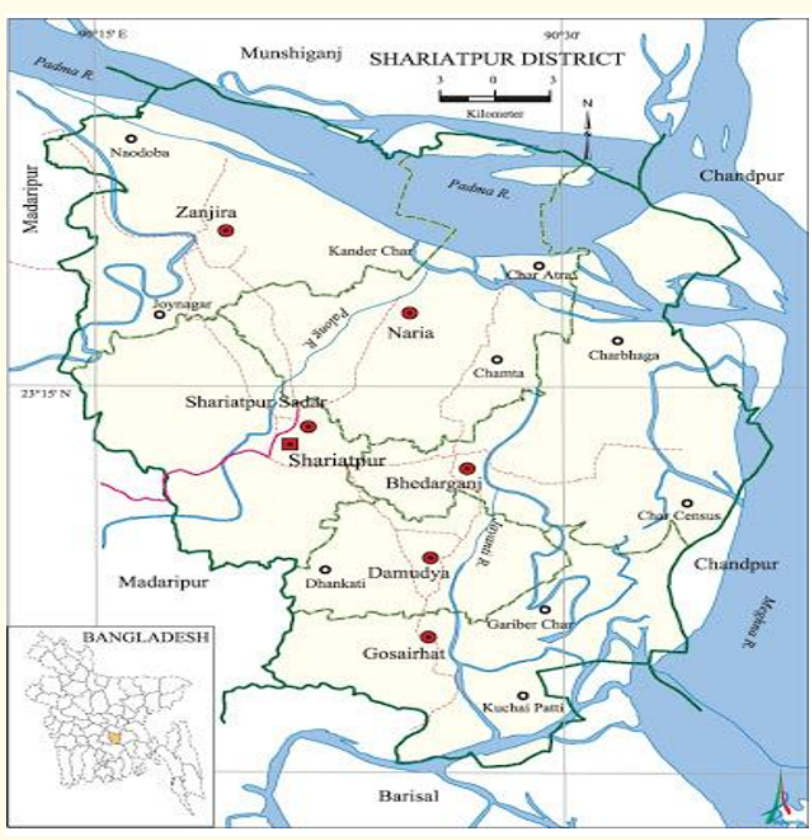

Figure 1: Research field "Source: Google map".

\section{Study period}

The study was carried out between $1^{\text {st }}$ Sep 2020 to $28^{\text {th }}$ Feb 2021.

\section{Sample size}

Since it is a cross-sectional study, the following formula was used for sample size collection: $=n=\frac{z^{2} p q}{d^{2}}$

Here,

$\mathrm{n}=$ Sample size

$\mathrm{z}=$ Confidence level of interest (for $95 \%=1.96$ )

$\mathrm{p}=0.50[\text { Probability of success }(50 \%)]^{[* 4]}$

$d=$ Tolerance level of error $5 \%(0.05)$.

So, required sample size $=$

$n=\frac{z^{2} p q}{d^{2}}=(1.96)^{2} X[(0.5)(1-0.5)] \div(0.05)^{2} \cong 384$.

Sample size 384 .

Inclusion criteria

Respondents would have to fulfil the following to be considered for this study.

- $\quad$ People who are residing in the flood-affected union of Shariatpur
- $\quad$ Aged 20 years or above

- $\quad$ Both male and female participants who agreed to give consent

- $\quad$ Able to understand the questions of WHOQOL-BREF.

\section{Exclusion criteria}

- $\quad$ People who belong to the same family.

\section{Sampling technique}

To measure the impact of the flood crisis on quality of life, convenience sampling was used. 384 people took part in this poll. Every one of the individuals who were ready to take part in the program and met the eligibility requirements were selected.

\section{Data collection tools}

After obtaining informed consent, a self-administrated questionnaire (pre-coded and open-ended) used to collect the demographic information and the WHOQOL-BREF questionnaire was administered to measure every aspect of people's quality of life by face-to-face interview technique. However, no measures were taken as part of the analysis.

\section{WHOQOL-BREF scale}

The WHOQOL-BREF is the short 26-item form of the larger WHOQOL-100 assessment [37] that yields four QOL domains: physical health (7 items; e.g., "How much do you need medical treatment to function in your daily life?"), psychological QOL (6 items; e.g., "To what extent do you feel life to be meaningful?"), social QOL (3 items; e.g., "How satisfied are you with your personal relationships?"), and environmental QOL (8 items; e.g., "How safe do you feel in your daily life?"). The psychometric qualities of the WHOQOL-BREF have been studied using cross-sectional data from 11,830 individuals from 23 countries, and it has been found to be a reliable evaluation across cultures and socioeconomic status [37].

\section{Data management and analysis plan}

To measure individual quality of life, separate measuring scores for quality of life and socio-economic data will be used in this analysis. To evaluate the relationship between dependent and independent variables, cross tabulation would be used. For examining the distribution of each variable, descriptive analyses of sociodemographic and exposure factors, as well as quality of life, will be performed, and descriptive statistics will be measured for each variable. The bivariate relationship between the socio-demograph- 
ic and exposure variables will be assessed using the Pearson chisquare test. Multivariable logistic regression used to evaluate the effect of flooding on quality of life and to assess the future risk of a flood occurrence. The events was graded using clinical scoring. Stepwise regression analyses was used to evaluate all the independent variables for each dependent variable. The logit coefficient will be calculated, as well as the $95 \%$ confidence intervals. The level of statistical significance will be set at $5 \%$. All analyses will be carried out using the STATA (version 16).

Quality control and quality assurance

The study aims to identify quality-of-life problems in flooded areas and thus data is gathered through face-to-face interviews. The study's instrument was a questionnaire created by the researchers to collect data and consisted of many sections which aimed at finding out the respondent's opinion. Furthermore, it addresses study plans, analysis and methods of evaluation and we are using simple random sampling which represent the whole population. For data interpretation and evaluating the study hypotheses, a chi-square test will be used. Data review and final report writing will be done by Researcher himself. Quality also will be maintained during data collection and report presentation with the required guidance from the department of public health, NSU.

\section{Ethical considerations}

Before starting the study, all necessary administrative approvals obtained from the responsible authorities (NSU ethical committee, $\mathrm{NGH}$ and CRI authorities, GoB). The confidentiality of the respondents assured and maintained by the researcher. Before enrolling in the sample, the respondents asked to give their verbal informed consent.

\section{Limitations of the study}

- WHOQOL-BREF questionnaire was used to analyze data exclusively in the post-flood period; no pre-flood data were assessed in this study.

- $\quad$ This is not a cohort study; just one cross-sectional survey was done for data collection after the flood; hence, a direct comparison of health-related quality of life at the individual level between pre- and post-flood is not possible in this study.
- It would be better if it could be done across the division.

\begin{tabular}{|c|c|c|}
\hline Sample Characteristics & $\begin{array}{c}\text { Sample } \\
\text { distribution } \\
\text { (n= frequency) }\end{array}$ & $\begin{array}{c}\text { Percentage (\%) } \\
\text { Mean (SD) }\end{array}$ \\
\hline Age & 384 & 43.56 \\
\hline \multicolumn{3}{|l|}{ Sex } \\
\hline Male & 277 & 72.14 \\
\hline Female & 107 & 27.86 \\
\hline \multicolumn{3}{|l|}{ Age Group } \\
\hline Young (21-30) & 57 & 14.84 \\
\hline Young Adult (31-40) & 113 & 29.43 \\
\hline Middle Age (41-50) & 88 & 22.92 \\
\hline Old (51-60) & 105 & 27.34 \\
\hline Older (Above 60) & 21 & 5.47 \\
\hline \multicolumn{3}{|l|}{ Upazila } \\
\hline Damudya & 100 & 26.04 \\
\hline Shariatpur Sadar & 284 & 73.96 \\
\hline \multicolumn{3}{|l|}{ Marital Status } \\
\hline Single & 6 & 1.56 \\
\hline Married & 340 & 88.54 \\
\hline $\begin{array}{l}\text { Divorced/Separated/ } \\
\text { Widow }\end{array}$ & 38 & 9.90 \\
\hline \multicolumn{3}{|l|}{ Total house Member } \\
\hline Small $(<4)$ & 189 & 49.22 \\
\hline Medium $(<6)$ & 112 & 29.17 \\
\hline Large $(<9)$ & 40 & 10.42 \\
\hline Very Large (Above 9) & 43 & 11.20 \\
\hline \multicolumn{3}{|l|}{ No of Children } \\
\hline No Children & 15 & 3.91 \\
\hline One Child & 88 & 22.92 \\
\hline Two Child & 144 & 37.50 \\
\hline Three Child & 93 & 24.22 \\
\hline Four Child & 38 & 9.90 \\
\hline Five or more child & 6 & 1.56 \\
\hline \multicolumn{3}{|c|}{ Number of Sources of income } \\
\hline One person & 317 & 82.55 \\
\hline Two persons & 63 & 16.41 \\
\hline >Two persons & 4 & 1.04 \\
\hline
\end{tabular}




\begin{tabular}{|c|c|c|}
\hline \multicolumn{3}{|l|}{ Education } \\
\hline $\begin{array}{l}\text { No education and Pre- } \\
\text { school }\end{array}$ & 24 & 6.25 \\
\hline Primary & 30 & 7.81 \\
\hline Secondary & 91 & 23.70 \\
\hline Higher & 26 & 6.77 \\
\hline College & 77 & 20.05 \\
\hline University & 136 & 35.42 \\
\hline \multicolumn{3}{|c|}{ Income } \\
\hline \multicolumn{3}{|c|}{ Pre-Flood } \\
\hline Low (Up to 10,000 ) & 72 & 18.75 \\
\hline Middle $(>10,000-25,000)$ & 204 & 53.13 \\
\hline Upper Middle $(>25,000)$ & 108 & 28.13 \\
\hline \multicolumn{3}{|c|}{ During Flood } \\
\hline Low (Up to 10,000 ) & 134 & 34.90 \\
\hline Middle $(>10,000-25,000)$ & 180 & 46.88 \\
\hline Upper Middle (>25,000) & 70 & 18.23 \\
\hline \multicolumn{3}{|c|}{ Source of Income } \\
\hline Agriculture & 27 & 7.03 \\
\hline Transport & 3 & 0.78 \\
\hline Garments & 34 & 8.85 \\
\hline Day labour & 31 & 8.07 \\
\hline Self Employed Business & 63 & 16.41 \\
\hline Fishing & 3 & 0.78 \\
\hline Poultry & 17 & 4.43 \\
\hline Government & 93 & 24.22 \\
\hline Private & 111 & 28.91 \\
\hline Others & 2 & 0.52 \\
\hline \multicolumn{3}{|c|}{ Domestic Violence } \\
\hline No violence & 368 & 95.83 \\
\hline Physical violence & 15 & 3.91 \\
\hline Verbal/Emotional & 1 & 0.26 \\
\hline \multicolumn{3}{|c|}{ Living in Self House } \\
\hline Yes & 237 & 62.53 \\
\hline No & 142 & 37.47 \\
\hline \multicolumn{3}{|c|}{ Presence of Chronic Disease } \\
\hline \multicolumn{3}{|c|}{ Central Nervous System } \\
\hline Yes & 71 & 18.49 \\
\hline No & 313 & 81.51 \\
\hline
\end{tabular}

\begin{tabular}{|c|c|c|}
\hline \multicolumn{3}{|c|}{ Cancer } \\
\hline Yes & 9 & 2.34 \\
\hline No & 375 & 97.66 \\
\hline \multicolumn{3}{|c|}{ Respiratory Disease } \\
\hline Yes & 108 & 28.13 \\
\hline No & 276 & 71.88 \\
\hline \multicolumn{3}{|c|}{ Diabetes } \\
\hline Yes & 95 & 24.74 \\
\hline No & 289 & 75.26 \\
\hline \multicolumn{3}{|c|}{ WHOQOL-BREF (Quality of Life) } \\
\hline \multicolumn{3}{|c|}{ Physical Health } \\
\hline Poor Physical Health & $162(42.19)$ & \multirow[t]{2}{*}{23.46} \\
\hline Good Physical Health & $222(57.81)$ & \\
\hline \multicolumn{3}{|c|}{ Psychological Health } \\
\hline $\begin{array}{c}\text { Poor Psychological } \\
\text { Health }\end{array}$ & $162(42.19)$ & \multirow[t]{2}{*}{17.59} \\
\hline $\begin{array}{c}\text { Good Psychological } \\
\text { Health }\end{array}$ & $222(57.81)$ & \\
\hline \multicolumn{3}{|c|}{ Social Relationship } \\
\hline Poor Social relation & $171(44.53)$ & \multirow[t]{2}{*}{10.52} \\
\hline Good Social relation & $213(55.47)$ & \\
\hline \multicolumn{3}{|c|}{ Environment } \\
\hline Poor environment & $198(51.56)$ & \multirow[t]{2}{*}{22.31} \\
\hline Good environment & $186(48.44)$ & \\
\hline
\end{tabular}

Table 1: Sample characteristics of the study population $(n=384)$.

\section{Results and Discussion}

Sample characteristics of the study population

Table 1 displays the demographics of the Shariatpur district study population, with $26 \%$ hailing from Shariatpur Sadar and 74\% from Damudya upazilla. In total, 384 persons took part in the study, 277 (72\%) of whom were men and 107 (28\%) of whom were women. The average age of the study participants was 43.56 years. In the study population, $29 \%$ were $31-40$ years old, $27 \%$ were $51-60$ years old, $23 \%$ were $41-50$ years old, $15 \%$ were $21-30$ years old, and $5 \%$ were over 60 years old. In the study population, $89 \%$ were married, $2 \%$ were single, and $10 \%$ were divorced. $49 \%$ of respondents came from families with fewer than four members, $29 \%$ from families with fewer than six but more than four members, $10 \%$ from families with fewer than nine but more than six members, and $11 \%$ from families with more than nine members. 
$37 \%$ of respondents had two children, while $24 \%$ had three children, only $2 \%$ of respondents had five or more children, with $23 \%$ having one child, $10 \%$ having four children, $4 \%$ having no children. Only $1 \%$ of the respondents had more than two people to contribute to their family's income. $83 \%$ of the respondents were the only income source in their family, $16 \%$ had another person to contribute to family income besides him/her, and only $1 \%$ had more than two people to contribute to family income besides him/ her. The majority of respondents (35\%) completed up to university level education, while $24 \%$ completed up to secondary level education, $20 \%$ completed up to college-level education, $8 \%$ completed up to primary level education, $7 \%$ completed up to higher secondary level education, and 6\% completed up to primary level education. Private job holders accounted for $29 \%$ of the respondents, while government employees accounted for $24 \%$, day labourers accounted for $16 \%$, self-employed businesses accounted for $11 \%$, and garments accounted for $9 \%$. Agriculture accounted for $7 \%$ of the respondents, while fishing accounted for $3 \%$ and poultry accounted for $2 \%, 1 \%$ of the population worked in transportation, while $1 \%$ worked in other occupations.

During the pre-flood period, $28 \%$ of participants had monthly incomes of more than 25000 BDT, 53\% had monthly incomes of between 10000 and 250000 BDT, and 19\% had monthly incomes of less than 10000 BDT, but during the flood period, only $18 \%$ of participants had monthly incomes of more than 25000 BDT, and $47 \%$ had monthly incomes of less than 10000 BDT. $63 \%$ of the participants were self-sufficient. The remaining participants shared a leased home.

In cases of family violence against female partners, whether physical, verbal, or emotional, it was discovered that less than $1 \%$ of female partners were subjected to verbal/emotional abuse and $4 \%$ of female couples were subjected to physical violence by their male partners. $95 \%$ of partners had no physical, verbal, or emotional abuse from their male counterparts.

It was observed that $82 \%$ of the people did not have any chronic conditions that caused central nervous system abnormalities. Only $18 \%$ of the individuals suffered from central nervous system problems. Despite the fact that $98 \%$ of the participants had no cancerrelated diseases, just $2 \%$ of the participants had cancer-related disorders. $72 \%$ of those polled said they had no respiratory infections. Only $28 \%$ of the participants reported respiratory issues. $75 \%$ of those polled said they did not have diabetes.

\begin{tabular}{|c|c|c|c|c|c|}
\hline \multirow{2}{*}{ Variable } & \multirow{2}{*}{ Traits } & \multicolumn{4}{|c|}{ Quality of Life - Physical Activity } \\
\hline & & Poor & Good & $\chi^{2}$ & p-value \\
\hline \multirow[t]{2}{*}{ Gender } & Male & $98(35.38 \%)$ & $179(64.62 \%)$ & \multirow[t]{2}{*}{18.89} & \multirow[t]{2}{*}{$<0.0001$} \\
\hline & Female & $64(59.81 \%)$ & $43(40.19 \%)$ & & \\
\hline \multirow[t]{5}{*}{ Age } & $21-30 y$ & 17 (29.82\%) & $40(70.18 \%)$ & \multirow[t]{5}{*}{19.22} & \multirow[t]{5}{*}{0.001} \\
\hline & $31-40 y$ & $39(34.51 \%)$ & $74(65.49 \%)$ & & \\
\hline & $41-50 y$ & 35 (39.77\%) & $53(60.23 \%)$ & & \\
\hline & $51-60 y$ & $56(53.33 \%)$ & $49(46.67 \%)$ & & \\
\hline & Above $60 \mathrm{y}$ & $15(71.43 \%)$ & $6(28.57 \%)$ & & \\
\hline \multirow[t]{6}{*}{ Education Level } & No/ Pre-school & $21(87.50 \%)$ & $3(12.50 \%)$ & \multirow[t]{6}{*}{47.83} & \multirow[t]{6}{*}{$<0.0001$} \\
\hline & Primary & $23(76.67 \%)$ & $7(23.33 \%)$ & & \\
\hline & Secondary & $42(46.15 \%)$ & $49(53.85 \%)$ & & \\
\hline & Higher Secondary & $11(42.31 \%)$ & $15(57.69 \%)$ & & \\
\hline & College & $26(33.77 \%)$ & $15(66.23 \%)$ & & \\
\hline & University & $39(28.68 \%)$ & 97 (71.32\%) & & \\
\hline \multirow{2}{*}{$\begin{array}{l}\text { Cardiovascular } \\
\text { Disease }\end{array}$} & Yes & $56(94.92 \%)$ & $3(5.08 \%)$ & \multirow{2}{*}{\multicolumn{2}{|c|}{0.000 (Fisher's exact) }} \\
\hline & No & $106(32.62 \%)$ & $219(67.38 \%)$ & & \\
\hline
\end{tabular}




\begin{tabular}{|c|c|c|c|c|c|}
\hline \multirow{2}{*}{$\begin{array}{l}\text { Respiratory } \\
\text { Disease }\end{array}$} & Yes & $83(76.85 \%)$ & $25(23.15 \%)$ & \multirow[t]{2}{*}{74.02} & \multirow[t]{2}{*}{$<0.0001$} \\
\hline & No & $79(28.62 \%)$ & $197((71.38 \%)$ & & \\
\hline \multirow[t]{2}{*}{ Malignancy } & Yes & $9(100 \%)$ & $0(0 \%)$ & \multirow{2}{*}{\multicolumn{2}{|c|}{0.000 (Fisher's exact) }} \\
\hline & No & $153(40.80 \%)$ & $222(59.20 \%)$ & & \\
\hline \multirow[t]{3}{*}{ Diabetes Mellitus } & Yes & $73(76.84 \%)$ & $22(23.16 \%)$ & \multirow[t]{2}{*}{62.15} & \multirow[t]{2}{*}{$<0.0001$} \\
\hline & No & $89(30.80 \%)$ & $200(69.20 \%)$ & & \\
\hline & & \multicolumn{4}{|c|}{ Quality of Life - Psychological } \\
\hline \multirow[t]{2}{*}{ Gender } & Male & $88(31.77 \%)$ & $189(68.23 \%)$ & \multirow[t]{2}{*}{44.24} & \multirow[t]{2}{*}{$<0.0001$} \\
\hline & Female & $74(69.16 \%)$ & $33(30.84 \%)$ & & \\
\hline \multirow{3}{*}{$\begin{array}{l}\text { Domestic Vio- } \\
\text { lence }\end{array}$} & No & $148(42.12 \%)$ & $220(57.88 \%)$ & \multirow{3}{*}{\multicolumn{2}{|c|}{0.000 (Fisher's exact) }} \\
\hline & Physical & $14(93.33 \%)$ & $1(6.67 \%)$ & & \\
\hline & Verbal/Emotional & $0(0 \%)$ & $1(100 \%)$ & & \\
\hline \multirow[t]{3}{*}{ Malignancy } & Yes & $9(100 \%)$ & $0(0 \%)$ & \multirow[t]{2}{*}{12.62} & \multirow[t]{2}{*}{$<0.0001$} \\
\hline & No & $153(40.80 \%)$ & $222(59.20 \%)$ & & \\
\hline & & \multicolumn{4}{|c|}{ Quality of Life - Social Relationship } \\
\hline \multirow[t]{2}{*}{ Gender } & Male & $107(38.63 \%)$ & $170(61.37 \%)$ & \multirow[t]{2}{*}{14.02} & \multirow[t]{2}{*}{$<0.0001$} \\
\hline & Female & $64(59.81)$ & $43(40.19 \%)$ & & \\
\hline \multirow[t]{6}{*}{ Education Level } & No/ Pre-school & $19(79.17 \%)$ & $5(20.83 \%)$ & \multirow[t]{6}{*}{40.16} & \multirow[t]{6}{*}{$<0.0001$} \\
\hline & Primary & $24(80.00 \%)$ & $6(20.00 \%)$ & & \\
\hline & Secondary & $44(48.35 \%)$ & $47(51.65 \%)$ & & \\
\hline & Higher secondary & $14(53.85 \%)$ & $12(46.15 \%)$ & & \\
\hline & College & $26(33.77 \%)$ & $51(66.23 \%)$ & & \\
\hline & University & $44(32.35 \%)$ & $92(67.65 \%)$ & & \\
\hline \multirow{4}{*}{$\begin{array}{l}\text { Domestic Vio- } \\
\text { lence }\end{array}$} & No & $155(42.12 \%)$ & $213(57.88 \%)$ & \multirow{3}{*}{\multicolumn{2}{|c|}{0.000 (Fisher's exact) }} \\
\hline & Physical & $15(100 \%)$ & $0(0 \%)$ & & \\
\hline & Verbal/emotional & $1(100 \%)$ & $0(0 \%)$ & & \\
\hline & & \multicolumn{4}{|c|}{ Quality of Life - Environment } \\
\hline \multirow[t]{2}{*}{ Gender } & Male & $115(41.52 \%)$ & $162(58.48 \%)$ & \multirow[t]{2}{*}{40.17} & $<0.0001$ \\
\hline & Female & $83(77.57 \%)$ & $24(22.43 \%)$ & & \\
\hline Education Level & No/ Pre-school & $19(79.17 \%)$ & $5(20.83 \%)$ & & \\
\hline & Primary & $28(93.33 \%)$ & $2(6.67 \%)$ & & \\
\hline & Secondary & $55(60.44 \%)$ & $36(39.56 \%)$ & & \\
\hline & Higher secondary & $7(26.92 \%)$ & $19(73.08 \%)$ & $0.000(\mathrm{~F}$ & er's exact) \\
\hline & College & $35(45.45 \%)$ & $42(54.55 \%)$ & & \\
\hline & University & $54(39.71 \%)$ & $82(60.29 \%)$ & & \\
\hline
\end{tabular}

Table 2: Four domains of Quality of Life (QoL). 
Table 2 shows the gender-based disparities in physical healthrelated quality of life on WHOQOL-BREF. During the flood period, $35.38 \%$ of participants in the Shariatpur district had poor physical health, compared to $59.81 \%$ of female respondents who had the poor physical health-related quality of life. The Pearson chi-square test revealed that during the floods in the Shariatpur district, there are substantial gender-based disparities in the connection of physical health-related quality of life. Age-related changes are seen in physical health-related quality of life, physical health was poor only in $29.82 \%$ of the 57 participants between the ages of 21 and 30 . A total of $34.51 \%$ of 113 adults aged 31 to 40 were found with poor physical health, while $60.23 \%$ had good physical condition. A total of $39.77 \%$ of 88 adults aged 41 to 50 had a poor physical health, while $60.23 \%$ had a good physical health. In a sample of 105 persons aged 51 to $60,53.33 \%$ reported poor physical health, whereas $46.67 \%$ had great physical health. The Pearson chi-square test revealed that there are significant age group-based differences in physical health-related quality of life during floods in Shariatpur district, with the most vulnerable age group being over 60 years, with $71.43 \%$ of participants reporting poor physical health-related quality of life.

$87.50 \%$ of the 24 participants with no or only preschool education experienced poor physical health-related quality of life, whereas only $12.50 \%$ had good physical health-related quality of life. $76.67 \%$ of the 30 participants with a primary education experienced good physical health-related quality of life, while $23.33 \%$ had excellent physical health-related quality of life. $46.15 \%$ of the 91 participants with a secondary education exhibited a bad physical health-related quality of life, whereas $53.85 \%$ had a high physical health-related quality of life. $42.31 \%$ of the 26 participants with higher secondary education had a bad physical health-related quality of life, whereas $57.69 \%$ had a good physical health-related quality of life. A total of $33.77 \%$ of the 41 participants with a college diploma had a bad physical health-related quality of life, while $66.23 \%$ had a high physical health-related quality of life. Only $28.68 \%$ of the 136 participants with a university credential had a poor physical health-related quality of life, whereas $71.32 \%$ had a good physical health-related quality of life. Table 2 also shows the association of cardiovascular disease with physical health-related quality of life on the WHOQOL-BREF scale. $94.92 \%$ of those with cardiovascular disease suffered bad physical health-related quality of life, while only $5.08 \%$ had good physical health-related quality of life. Out of 325 participants without cardiovascular disease, $32.62 \%$ suffered from poor physical health-related quality of life, while $67.38 \%$ expressed a high physical health-related quality of life.

$76.85 \%$ with respiratory disease had a poor physical healthrelated quality of life, while $23.15 \%$ of those without respiratory disease had a poor physical health-related quality of life. In a group of 276 people, $28.62 \%$ had a bad physical health-related quality of life, whereas $71.32 \%$ had a good physical health-related quality of life.

The connection between physical health-related quality of life and the presence or absence of cancer disease on the WHOQOLBREF scale. Only nine people in the study had cancer, and they all had the poor health-related quality of life. Out of 375 individuals without cancer, $40.80 \%$ had a bad physical health-related quality of life, whereas $59.20 \%$ had a high physical health-related quality of life. $76.84 \%$ of those with diabetes mellitus suffered bad physical health-related quality of life, while $23.16 \%$ had the good physical health-related quality of life. Out of 289 individuals without diabetes mellitus, $30.80 \%$ had a bad physical health-related quality of life, whereas $69.20 \%$ had a high physical health-related quality of life.

On WHOQOL-BREF, gender-based discrepancies in psychological health-related quality of life were shown in Table 2. During the floods, $31.77 \%$ of Shariatpur district male participants had a poor physical health-related quality of life, while $69.16 \%$ of female participants had a poor psychological health-related quality of life. The Pearson chi-square test found that there was significant genderbased discrepancies in the relation of psychological health-related quality of life during the floods in the Shariatpur district.

Male partners did not suffer any type of domestic abuse based on domestic violence. Domestic abuse affected $4.16 \%$ of females. Domestic violence had been experienced by 16 of the 107 female participants. Up to $93.3 \%$ of female respondents who had experienced physical violence had a low psychological health-related quality of life. On the contrary. Female participants who had been subjected to verbal/emotional abuse did not have a poor psychological health-related quality of life. Only nine people in the study had cancer, and they all had the poor psychological health-related quality of life. Out of 375 individuals without cancer, $40.80 \%$ had a bad psychological health-related quality of life, whereas $59.20 \%$ had a high psychological health-related quality of life. During the flood period, $38.63 \%$ of male participants in the Shariatpur district had bad social relationship, compared to $59.81 \%$ of female partici-

Citation: Md Abeed Hasan., et al. "Impact of Flooding on Quality of Life in Shariatpur of Bangladesh: A Cross-Sectional Study". Acta Scientific Medical Sciences 6.1 (2022): 48-61. 
pants who had the poor social relationship. The Pearson chi-square test revealed that during the floods in the Shariatpur district, there are substantial gender-based disparities in the connection of social relationship.

Table 2 shows the level of social relationship of life on the WHOQOL-BREF scale based on education. $79.17 \%$ of the 24 participants with no or only preschool education experienced poor social relationship, whereas $20.83 \%$ had high social relationship with others. $80.00 \%$ of the 30 participants with a primary education experienced good social relationship with others, while $20.00 \%$ had excellent social relationship with others. $48.35 \%$ of the 91 participants with a secondary education exhibited a bad social relationship with others, whereas $51.65 \%$ had a high social relationship. $53.85 \%$ of the 26 participants with higher secondary education had a bad social relationship, whereas $46.15 \%$ had a good social relationship. A total of $33.77 \%$ of the 77 participants with a college diploma had a bad social relationship, while $66.23 \%$ had a high social relationship with others. Only $32.35 \%$ of the 136 participants with a university credential had a poor social relationship, whereas $67.65 \%$ had a high social relationship. Among those respondents who had never experienced domestic abuse, $42.12 \%$ had poor social relationships with others and $57.88 \%$ had strong social relationships with others. On the other hand, those who had experienced physical or verbal domestic violence had all had bad social ties with others.

77.57\% female respondents experienced living in poor environment and on the contrary $58.48 \%$ male respondents experienced living in good environment. $79.17 \%$ of the 24 participants with no or only preschool education experienced living in poor environment, whereas $20.83 \%$ had experienced high living environment. Only $6.67 \%$ of the 30 participants with a primary education experienced living in good environment. $60.44 \%$ of the 91 participants with a secondary education exhibited a bad environment, whereas $39.56 \%$ had experienced a good living environment. $26.92 \%$ of the 26 participants with higher secondary education had experienced living in poor environment, whereas $73.08 \%$ had experience of living in good environment. A total of $45.45 \%$ of the 77 participants with a college diploma had a poor environment experience, while $54.55 \%$ had experience of living in a good environment. Only $39.71 \%$ of the 136 participants with a university credential had poor experience of living, whereas $60.20 \%$ had experience of living in good environment.

\begin{tabular}{|c|c|c|c|c|c|}
\hline \multirow{2}{*}{ Variable } & \multirow{2}{*}{ Traits } & \multirow{2}{*}{$\beta$ coef. } & \multicolumn{2}{|c|}{ 95\% Conf. Interval } & \multirow{2}{*}{ p-value } \\
\hline & & & Lower & Upper & \\
\hline \multirow[t]{2}{*}{ Gender } & Male & 3.71 & 1.73 & 5.70 & $<0.0001$ \\
\hline & Female* & - & & & \\
\hline \multirow[t]{3}{*}{ Income (during flood) } & $<10,000$ BDT* & - & & & \\
\hline & $\begin{array}{c}10,000 \text { BDT }-25,000 \\
\text { BDT }\end{array}$ & 3.87 & 1.99 & 5.75 & $<0.0001$ \\
\hline & $>25,000 \mathrm{BDT}$ & 10.60 & 8.18 & 13.01 & $<0.0001$ \\
\hline \multirow[t]{6}{*}{ Education } & No education & 8.01 & 3.98 & 12.03 & $<0.0001$ \\
\hline & Primary & -0.002 & -3.68 & 3.67 & 0.999 \\
\hline & Secondary & 8.49 & 5.47 & 11.50 & $<0.0001$ \\
\hline & Higher Sec.* & - & & & \\
\hline & College & 3.78 & 0.76 & 6.80 & 0.014 \\
\hline & University & 5.31 & 2.53 & 8.09 & $<0.0001$ \\
\hline \multirow[t]{5}{*}{ Age } & $21-30 y$ & 2.12 & -0.46 & 4.71 & 0.108 \\
\hline & $31-40 y$ & 1.19 & -0.99 & 3.39 & 0.282 \\
\hline & $41-50 y^{*}$ & & & & \\
\hline & $51-60 y$ & -0.18 & -2.12 & 1.75 & 0.849 \\
\hline & Above $60 \mathrm{y}$ & -0.10 & -3.17 & 2.95 & 0.944 \\
\hline
\end{tabular}




\begin{tabular}{|c|c|c|c|c|c|}
\hline \multirow[t]{3}{*}{ Marital Status } & Single & 4.91 & -2.11 & 11.94 & 0.170 \\
\hline & Married & 10.48 & 7.48 & 13.48 & 0.000 \\
\hline & Divorced/Widowed* & & & & \\
\hline $\begin{array}{c}\text { Cardiovascular Dis- } \\
\text { ease }\end{array}$ & No (Yes*) & 7.69 & 5.34 & 10.05 & $<0.0001$ \\
\hline Respiratory Disease & No (Yes*) & 4.39 & 2.34 & 6.44 & $<0.0001$ \\
\hline $\mathrm{DM}$ & No (Yes*) & 3.91 & 1.88 & 5.93 & $<0.0001$ \\
\hline \multirow[t]{6}{*}{ Number of Children } & One child & -1.94 & -6.33 & 2.45 & 0.385 \\
\hline & Two children & -2.58 & -7.09 & 1.91 & 0.260 \\
\hline & Three children & -4.54 & -9.28 & 0.18 & 0.060 \\
\hline & Four children & -5.35 & -10.42 & -0.28 & 0.039 \\
\hline & Five children* & & & & \\
\hline & Five or more children & -3.57 & -10.63 & 3.48 & 0.320 \\
\hline Living own house & Yes $\left(\mathrm{No}^{*}\right)$ & -0.82 & -2.35 & 0.69 & 0.287 \\
\hline \multirow[t]{4}{*}{ Family Member } & Small $(<4) *$ & - & & & \\
\hline & Medium $(<6)$ & -1.14 & -3.23 & 0.95 & 0.283 \\
\hline & Large $(<9)$ & -1.40 & -4.20 & 1.38 & 0.323 \\
\hline & Very Large ( 9 or more) & -0.74 & -3.70 & 2.22 & 0.623 \\
\hline
\end{tabular}

Table 3: Significant factors associated with four domains of Quality of Life (QoL).

Floods, in general, reduce the quality of life, and flood victims will feel this effect. Only the severity of the victim's quality of life varied from victim to victim. In this study, the impact of floods was found to be stronger in the physical and psychological domains. This conclusion was consistent with previous investigations. In this study, flood victims with low quality of life had a stronger impact, particularly those who resided along the riverbank, women, and those with lower socioeconomic levels. Women's quality of life was adversely reduced by a natural disaster such as a flood.

After being impacted by the flood, the average score for quality of life was $26.26 \pm 5.15$. There was no statistical significance in the overall number of family members, having children, and owning a home. In our research, we discovered that those with a monthly income of more than 25,000 BDT, as well as those who were educated and married, had higher quality-of-life scores. The linear regression model revealed that respondents above the age of 41 had a poor quality of life. When compared to those who have had congenital and chronic disorders, those who have not had those ailments had higher ratings. This large-scale cross-sectional study of adult persons was undertaken among adults in a waterlogged area of Shariatpur, Bangladesh, to assess Quality of Life (QoL) and its relationship with sociodemographic and clinical parameters. The mean quality of life score was $26.26 \pm 5.15$, indicating a bad quality of life in comparison to another study where on WHOQOL-BREF scale, Quality of Life was graded as excellent 110-89, good 88-67, fair 45-66 and Poor $<45$.

The quality of life of flood victims in several flood-affected upazillas of Shariatpur district was investigated. We discovered a large percentage of quality-of-life discrepancies across research participants from various upazillas in the Shariatpur district, which was significantly correlated with independent variables. The purpose of this research was to learn more about the sociodemographic features, mental and physical health status, and quality of life of persons living in flood-affected areas.

This study included 384 participants from various upazillas in Shariatpur district, with $73.96 \%$ hailing from Shariatpur Sadar upazilla, which is prone to floods every year. Male respondents (72.14\%) outnumbered female respondents (27.86\%). The answer per age category was $29.43 \%$ for those aged 31 to 40 years, $27.34 \%$ for those aged 51 to 60 years, $22.92 \%$ for those aged 41 to 50 years, 
$14.84 \%$ for those aged less than 31 years, and others for those aged over 60 years. The participants' average age was $43.56 \%$. The majority of them were married couples (88.54\%). Nuclear families (49.22\%) outnumber extended families (21.62\%), with $29.17 \%$ having 4-5 members, $10.42 \%$ having 6-8 members, and $11.12 \%$ having 9 or more members. $37.50 \%$ of married households have two children, $22.92 \%$ have one child, $24.22 \%$ have three children, $9.90 \%$ have four children, and the rest have five or more. The majority of the participants (35.42\%) were graduates, indicating that those residing in rural areas of the district had access to resources, including educational possibilities. The majority of the respondents (28.91\%) worked in the private sector, while $24.22 \%$ worked for the government, $16.41 \%$ ran a business, $8.85 \%$ worked in the garment industry, and others worked as farmers or day laborers. Almost half of them (46.88\%) had a monthly family income of 10,000 to $25,000 \mathrm{BDT}$, while $34.90 \%$ had a monthly income of less than 10,000 BDT. Among the sick, $18.49 \%$ had a central nervous system disease and $2.34 \%$ had cancer; among those with chronic disorders, $28.13 \%$ had respiratory disease and 24.74 percent had diabetes.

The majority of male respondents (68.23\%) had experienced high quality of life as per psychological domain, whereas about the same percentage $(69.16 \%)$ of female respondents had a poor psychological quality of life. Male respondents (61.37\%) were more likely than female respondents to have a good social relationship with others (40.19\%). There were no significant differences in social ties with others according to size of the family. People who completed their education had a good physical $(71.32 \%)$ quality of life, while those who were uneducated or had very little education $(87.50 \%)$ had a poor physical quality of life. Before or during the floods, there was no substantial link between quality of life and wealth disparities. Respondents earning less than 10,000 BDT $(65.57 \%)$ had the lowest psychological health-related quality of life. The findings of the study statistically signify that, respondents who earned 25,000 BDT or more per month is positively associated with quality of life.

Only female respondents suffered physical or mental domestic abuse, according to the findings of the survey. All the respondents who had been subjected to any form of violence had a poor social link with their peers and experienced poor psychological quality of life. Those with cardiovascular disease had a poor physical qual- ity of life, whereas those without cardiovascular illness had a poor physical quality of life, most respondents with respiratory disease (76.85\%) had a poor physical quality of life. According to the findings, everyone with cancer has a bad physical health-related quality of life. Floods, in general, diminished quality of life, and this effect will be felt by all flood victims. Only the intensity of the victim's quality of life differed from one victim to the next. The influence of QoL was shown to be greater in the physical and psychological domains in this study. This finding was in line with the findings of prior investigations. Low QoL had a greater impact on flood victims in this study, particularly those who lived along the riverbank, women, and those with lower socioeconomic status [9].

After a natural disaster such as a flood, women's QoL was severely impacted. This could be since women play an essential role in providing for the family livelihood. However, their tasks and workload may increase after the disaster and this may affect their well-being status [16]. Victims with low income suffer greater losses from floods than the households with high income [17]. However, this may be different in terms of their QoL status. The relationship between disaster losses and the level of economic development is nonlinear, suggesting that a country is more disaster resilience at a lower income level, but at a higher income level, a country become less disaster resistant [29]. Thus, this supports the poorer QOL in a lower socioeconomic situation.

\section{Strength of the study}

Because the limits of this study are described in section 3.15 of the research methodology, the study's strength is presented as follows -

- It is one of the rare studies that look at the adult population of a Bangladeshi district's quality of life. Education level, marriage status, number of family members, number of children, number of income sources, source of income, domestic violence, and sickness conditions are all analyzed socio-economic and flood-related aspects. Data were collected from the participants of severely flooded areas in different Upazila of Shariatpur District.

- In this study we assess socio-economic and independent factors with flood exposure and found a significant association which is consistent with the study conducted by Khandlhela, M. and May, J. 2006 [23]. 
- $\quad$ Because samples were obtained from separate Upazilas in the Shariatpur district, there was no risk of data duplication or the inclusion of the same subject's multiple times in this study.

\section{Direction for future research}

- $\quad$ Future research to assess quality of life will need to adopt a cohort study design, as most prior studies used cross-sectional studies.

- Because practically all prior research has focused on the immediate effects of flooding on health-related quality of life, long-term effects of flooding on quality of life must be studied to determine the specific reasons.

- $\quad$ Researchers should compare the status of quality of life of flooding in all regions to see if there are any similarities or disparities in health-related quality of life between developed and developing countries.

\section{Conclusion}

Flooding affects people who live in flood-prone locations on a yearly basis. The effects of floods on Quality of Life (QoL) among people who live in flood-prone locations were investigated in this study. Every year, flooding has a significant impact on people's health and quality of life [5]. People in the Shariatpur district suffered greatly because of the floods in 2020, according to this study. Many of those who were afflicted suffered from low health-related quality of life.

In Shariatpur's flood prone Upazila, most of the people come from lower socioeconomic backgrounds. They experienced enormous financial changes because of the floods. Along with the loss of lives and property, there was a significant fall in monthly revenue. Having to absorb losses during a flood, as well as coping with floodrelated losses, creates stress, which contributes to a poor healthrelated quality of life. Even though they were in desperate need of financial assistance, they received little from the government.

As a result, participants experienced more emotional distress and developed more symptoms. Following the floods, many people reported poor quality of life. Independent factors leading to poor quality of life are mostly found in lower-income populations, along with lower education levels, widowed or married populations, many family members, many children, a small number of income sources, day labor as a source of income, facing domestic violence, and having disease conditions, according to the analysis. The find- ings of this study will aid policymakers in improving early intervention and screening programs, as well as have major public health implications in Bangladesh's flood control and prevention efforts.

\section{Recommendation}

Following the completion of this study, certain recommendations were discovered. Among them are -

- To offer more specific and trustworthy statistics on the prevalence of health status and health-related quality of life across flood-affected areas, more samples should be added.

- Because of the poor quality of life prevalent among this demographic, policymakers must place a greater emphasis on strengthening health-related services.

- To improve health status understanding among rural people, health education and promotion must be stepped up. Flood forecasting in advance and frequent disaster management education will greatly assist individuals in effectively dealing with the flooding scenario.

- $\quad$ During floods, all government, non-government, and public health services must step up to provide the most comprehensive assistance to vulnerable people and communities, as well as necessary health care, in order to reduce the financial burden on vulnerable families and assist them in coping with the financial crisis.

\section{Acknowledgements}

I would want to express my gratitude to Prof. Dr. Ahmed Hossain sir, who is my study's supervisor and my corresponding supervisor Dr. Golam Mohammad, Associate Professor, Department of Pharmacy, Gono Bishwabidyalaya. Throughout my study, Dr. Ahmed Hossain sir and Dr. Golam Mohammod sir always encouraged and supported me, and they kept us on track to finish our study as soon as feasible. I will be eternally grateful to him for their patience, flexibility, and assistance during my thesis research.

We would like to thank the Department of Public Health, School of Health and Life Sciences, North South University (NSU), Dhaka, Bangladesh, for their assistance.

\section{Conflict of Interest}

None. 


\section{Bibliography}

1. "African Wildlife: Who is to blame for Floods?" 54.3 (2000): 24-25.

2. Andrea Jakubcová and Henrich Grežo. "Impacts of Flooding on the Quality of Life in Rural Regions of Southern Slovakia". Applied Research in Quality of Life 11 (2016): 221-237.

3. Ariyanbandu MM and Wickramasinghe WM. "Gender Dimension in Disaster Management: A guide for South Asia: Sri Lanka" (2005).

4. Ahmad Zaidin Othman. "Posttraumatic Stress Disorder and Quality of Life among Flood Disaster Victims". Procedia - Social and Behavioral Sciences 234 (2016): 125-134.

5. Bankoff G. "Constructing Vulnerability: The Historical, Natural and Social Generation of Flooding in Metropolitan Manila”. Disasters 27.3 (2003): 224-238.

6. Borrows P and De Bruin D. "The Management of Riverine Flood Risk". Irrigation and Drainage 55 (2006): S151-157.

7. Brouwer R., et al. "Socio-economic Vulnerability and Adaptation to Environmental Risk: A case study of Climate Change and Flooding in Bangladesh". Risk Analysis 27.2 (2017): 313.

8. Carey M. "Living and Dying with Glaciers: People's Historical Vulnerability to Avalanches and Outburst Floods in Peru". Global and Planetary Change 47 (2005): 122.

9. Chowdhury MHK and Hussain A. "Aridity and Drought Conditions of Bangladesh. Tropical Droughts (Meteorological Aspects and Implications for Agriculture)". Journal of WMO Program on Research in Tropical Meteorology. New Delhi, India (1981): 73-80.

10. Clare E French and Thomas D Waite. "Impact of repeat flooding on mental health and quality of life: a cross-sectional analysis of the English National Study of Flooding and Health". BMJ Open 9.11 (2019): e031562.

11. "Concept Note on the Comprehensive Vulnerability and Needs Assessment for Zambia” (2006).

12. Crossman M., et al. Proceedings of the In Civil Engineers. "A partnership approach to Managing Flood Risk". Civil Engineering Journal 159.2 (2006): 41-45.

13. David H Feeny., et al. "A Primer for Systematic Reviewers on the Measurement of Functional Status and Quality of Life in Older Adults" (2013).
14. Double JK. "Characteristics of River floods and Flooding: A Global Overview, 1985-2003”. Irrigation and Drainage 59 (2006): 59-521.

15. Flood plain management in Australia. "In Disaster risk Management". Study Guide for DIM 605: Module 2, Bloemfontein. University of the Free State (1998).

16. Fredrick Dermawan Purba., et al. "Living in uncertainty due to floods and pollution: the health status and quality of life of people living on an unhealthy riverbank". BMC Public Health (2018).

17. Gao J., et al. "An Assessment of Flood Hazard Vulnerability in the Dongting Lake Region of China". Lakes and Reservoirs Research and Management 12 (2017): 27-34.

18. Global assessment report on disaster risk reduction (2011).

19. Hanson k., et al. "A Framework for Evaluation of Flood Management Strategies". Journal of Environmental Management 86.3 (2007): 465-480.

20. H Z Tan and Y J Luo. "The effect of a disastrous flood on the quality of life in the Dongting Lake area in China". Asia-Pacific Journal of Public Health 16.2 (2014): 126-132.

21. Jose Jom Thomas and B Prakash. "Prevalence and severity of depression among people residing in flood-affected areas of Kerala". International Journal of Community Medicine and Public Health 6.3 (2019): 1143.

22. Jun $\mathrm{Wu}$ and Jian Xiao. "A cross-sectional survey on the health status and the quality of life of the elderly after flood disaster in Bazhong City, Sichuan, China". BMC Public Health 15 (2015): 163.

23. Khandlhela M and May J. "Poverty, Vulnerability and the Impact of Flooding in the Limpopo Province, School of Development Studies, University of Kwazulu Natal, South Africa". Natural Hazards 39 (2016): 275-287.

24. Known Risk. United Nations, Geneva, Switzerland (2005).

25. Kundzewicz ZW., et al. Natural Resources forum: "Coping with Variability and change: Floods and Droughts". NRF 26.4 (2002): 263-274.

26. Lind N., et al. "Structural Safety: Assessment and Affording the Control of Flood Risk". Structural Safety 31.2 (2008): 143-147.

27. Lindsell KM and Prater SC. "Assessing Community Impacts of National Disasters (electronic)". National Hazard Review 4.4 (2003): 176-178. 
28. "Living with Risk. A Global Review of Disaster Reduction Initiatives". United Nations Office for Disaster Risk Reduction, Geneva Switzerland (2002).

29. Milliman JD., et al. "Environmental and Economic Impact of Rising Sea Level and Subsiding Deltas: The Nile and Bengal Examples". In Bangladesh Quest 1 (1989): 11-12.

30. Mirza QMM., et al. Natural Hazards 28 (2003): 7.

31. Mustafa D. "Linking Access and Vulnerability: Perceptions of Irrigation and Flood Management in Pakistan". The Professional Geographer 34.1 (2002): 94-105.

32. Ninno DC., et al. "Public Policy, Markets and Household Coping Strategies in Bangladesh: Avoiding a Food Security Crisis Following the 1998 floods". World Development 31.7 (2003): 1221.

33. "Northern and Central Bangladesh Second Wave Flood - Briefing Note 6 August 2020" (2020).

34. Nott J. "Extreme Events: A Physical Reconstruction and Risk Assessment, Cambridge University Press, New York" (2006).

35. Parker JD. “Floods. Tangler and Francis, National Academy Press, Asian Disaster Preparedness Centre, Thailand". Journal of Geoscience and Environment Protection 4.8 (2000).

36. Pramanik MAH. "Natural Disasters. Article prepared for Bangladesh Space Research and Remote Sensing Organization (SPARRSO)". Dhaka, Bangladesh (1991).

37. Quality of Life | WHOQOL-BREF.

38. Rahman and Saleh Ur. "Impacts of flood on the lives and livelyhoods of people in Bangladesh: A case study of a village in Manikganj district". Institutional Respiratory (2014).

39. Rashid H and Pramanik MAH. "Visual Interpretation of Satellite Imagery for Monitoring Floods in Bangladesh". Environmental Management 14 (1990): 815-821.

40. Rashid FS. "The Urban Poor in Dhaka City: Their Struggles and coping strategies during the floods of 1998". Disasters 24.3 (2000): 240-253.

41. Sinclair S and Pegram G. "A Flood Now casting System for the eThekwini Metro, Volume 1: Urgent Now casting using Radar-An Integrated Pilot Study". Water Research Commission (WCR). Silowa Printers South Africa (2003).
42. Smith K and Ward R. "Floods: Physical processes and Human Impacts". John Wiley and son. England (1998).

43. Theron M. "Climate Change and Increasing Floods in Africa: Implication for Africa's Development" (2007).

\section{Assets from publication with us}

- Prompt Acknowledgement after receiving the article

- Thorough Double blinded peer review

- Rapid Publication

- Issue of Publication Certificate

- High visibility of your Published work

Website: www.actascientific.com/

Submit Article: www.actascientific.com/submission.php

Email us: editor@actascientific.com

Contact us: +919182824667 